ISSN 0258-7122

Bangladesh J. Agril. Res. 40(1): 17-34, March 2015

\title{
GRAIN YIELD, NUTRIENT BALANCE AND ECONOMICS OF T. AMAN RICE CULTIVATION AS INFLUENCED BY NUTRIENTS MANAGEMENT
}

\author{
M. A. H. S. JAHAN ${ }^{1}$, M A R SARKAR ${ }^{2}$, N. C. D. BARMA ${ }^{3}$ \\ M. N. A. MONDAL ${ }^{4}$, M. N. S. FERDOUSI ${ }^{5}$
}

\begin{abstract}
A field experiment was conducted at Regional Wheat Research Centre of the Bangladesh Agricultural Research Institute, Joydebpur, Gazipur, Bangladesh during 2007 and 2008. The objectives were to find out the optimum nutrient management practice for grain yield, nutrient balance and economics of $\mathrm{T}$. Aman rice. Twelve nutrient management treatments (with and without CRI) were tested in RCBD with 3 replications. Treatments were $\mathrm{T}_{1}=\mathrm{HYG}(0-80-16$ 44-12-2-0), T $2=$ MYG (0-56-12-32-8-1.5-0), T $3=$ IPNS (5000-65-13-32-9-2-0), $\mathrm{T}_{4}=$ STB $(0-68-15-37-11-2-0), \mathrm{T}_{5}=$ FP $(0-39-7-12-0-0-0), \mathrm{T}_{6}=$ CON $(0-0-0-0-0-0-$ $0), \mathrm{T}_{7}=\mathrm{HYG}+\mathrm{CRI}\left(\right.$ Crop residue incorporation), $\mathrm{T}_{8}=\mathrm{MYG}+\mathrm{CRI}, \mathrm{T}_{9}=\mathrm{IPNS}+\mathrm{CRI}$, $\mathrm{T}_{10}=\mathrm{STB}+\mathrm{CRI}, \mathrm{T}_{11}=\mathrm{FP}+\mathrm{CRI}, \mathrm{T}_{12}=\mathrm{CON}+\mathrm{CRI} \mathrm{kg} \mathrm{ha}^{-1} \mathrm{CDNPKSZnB}$ for T. Aman rice. On an average, maximum grain yield of T. Aman rice was obtained from STB+CRI (5.24 $\left.\mathrm{t} \mathrm{ha}^{-1}\right)$ followed by IPNS+CRI $\left(5.13 \mathrm{t} \mathrm{ha}^{-1}\right)$, STB $\left(5.12 \mathrm{t} \mathrm{ha}^{-1}\right)$, IPNS (5.03 $\left.\mathrm{t} \mathrm{ha}^{-1}\right), \mathrm{HYG}+\mathrm{CRI}$ (4.50 $\mathrm{ha}^{-1}$ ) and HYG (4.41 $\left.\mathrm{tha}^{-1}\right)$. Numerically but not statistically higher yield and yield contributing parameters were noticed in CRI plots than without CRI. Except $\mathrm{N}$ and $\mathrm{K}$ remaining nutrient balance like P S Zn and B were found positive in case of HYG, MYG, IPNS and STB along with or without CRI nutrient managements while FP and CON (Control) showed negative balance. The maximum BCR was observed in STB (3.25) followed by STB+CRI (3.14) and IPNS (2.98) and similar trend was observed in MBCR.
\end{abstract}

Keywords: T. Aman rice, yield, nutrient balance, nutrient management and crop residue incorporation

\section{Introduction}

Bangladesh is a country of 0.148 million sq.km and it has to feed about 150 million people (BBS, 2012). In order to produce more food within a limited area, two most important technique is to be adopted, which is to increase the productive efficiency of the individual crop depending on how well it utilizes the basic resources especially, the limiting ones, water and nutrients. Bangladesh is the fourth largest producer and consumer of rice in the world. Rice is the staple

\footnotetext{
${ }^{1}$ Principal Scientific Officer, Regional Wheat Research Center, BARI, Joydebpur, Gazipur, ${ }^{2}$ Professor, Department of Agronomy, Bangladesh Agricultural University, Mymensingh, ${ }^{3}$ Chief Scientific Officer, Regional Wheat Research Center, BARI, Joydebpur, Gazipur, ${ }^{4}$ Chief Scientific Officer, Regional Agricultural Research Station, BARI, Ishurdi, Pabna, ${ }^{5}$ SASP, PBI, BP, Dhaka, Bangladesh.
} 
food in Bangladesh. Rice is extensively grown in Bangladesh which covers $75 \%$ of the total cropped area and about $60 \%$ labor is engaged in rice production. Rice alone contributes around $10 \%$ to the GDP. Rice alone contributes about $95 \%$ to the total food grain production(BER,2010).It provides $75 \%$ of the calories and $55 \%$ of the proteins in the average daily diet of the people (Bhuiyan et al., 2002).The national mean yield $\left(2.60 \mathrm{t} \mathrm{ha}^{-1}\right)$ of rice in Bangladesh is lower than the potential national yield $\left(5.40 \mathrm{t} \mathrm{ha}^{-1}\right)$ and world average yield $\left(3.70 \mathrm{t} \mathrm{ha}^{-1}\right)$ (Pingaliet al., 1997). The lower yield of transplanted Aman rice has been attributed to several reasons, one of them being imbalanced nutrients management. Crop residue is a vital natural resource for conserving and sustaining soil productivity. It is the primary substrate for replenishment of soil organic matter. Upon mineralization, crop residue supplies essential plant nutrients (Walters et al., 1992). Additionally, residue incorporation can improve physical and biological conditions of the soil and prevent soil degradation (Nyborg et al., 1995). Incorporation of crop residues of either rice straw or wheat straw increased the yield and yield components of rice and nutrient uptake and also improved the physico-chemical properties of the soil, which provided better soil environment for crop growth. Increasing levels of NPK application increased the yield-attributing characters and nutrient uptake by both the crops, which ultimately increased the grain and straw yields (Das et al., 2003). Therefore, the present study was undertaken to find out the optimum nutrient management practice for grain yield, apparent nutrient balance in soil and economics of $\mathrm{T}$. Aman rice cultivation under AEZ-28.

\section{Materials and Method}

The experiment was carried out at the Regional Wheat Research Centre of Bangladesh Agricultural Research Institute Joydebpur, Gazipur. The experimental field of Gazipur belongs to the agro-ecological zone of Modhupur Tract (AEZ-28). The initial soil of the experimental field was analyzed for chemical properties before setting up the experiment. The initial soil status was $\mathrm{pH}$ 6.48, OM (\%) 1.07, Total $\mathrm{N}$ (\%) 0.055, available $\mathrm{P}\left(\mu \mathrm{g} \mathrm{g}^{-1}\right)$ 3.76, exchangeable $\mathrm{K}$ (meq $\left.100 \mathrm{~g}^{-1}\right)$ 0.15, available $\mathrm{S}\left(\mu \mathrm{gg}^{-1}\right)$ 9.91, available $\mathrm{Zn}\left(\mu \mathrm{g} \mathrm{g}{ }^{-1}\right)$ 0.24 and available $\mathrm{B}\left(\mu \mathrm{g} \mathrm{g}^{-1}\right)$ 0.16. Morphological characters are Grey Terrace soils, medium high land, not well drained, above flood level and grey soil clour. Physiological characters are silty loam to loam having more or less near neutral soil pH with very low to low soilfertility. T. Aman rice variety (BRRIdhan39) was tested in Kharif-II season during 2007 and 2008, respectively. Twelve nutrient management treatments were tested in RCBD with 3 replications. Treatments were $\mathrm{T}_{1}=\mathrm{HYG}(0-80-16-44-12-2-0), \mathrm{T}_{2}=\mathrm{MYG}(0-56-12-32-8-1.5-0)$, $\mathrm{T}_{3}=$ IPNS (5000-65-13-32-9-2-0), $\mathrm{T}_{4}=\mathrm{STB}(0-68-15-37-11-2-0), \mathrm{T}_{5}=\mathrm{FP}(0-39-7-$ $12-0-0-0), \quad \mathrm{T}_{6}=\mathrm{CON} \quad(0-0-0-0-0-0-0), \quad \mathrm{T}_{7}=\mathrm{HYG}+\mathrm{CRI}, \quad \mathrm{T}_{8}=\mathrm{MYG}+\mathrm{CRI}$, $\mathrm{T}_{9}=\mathrm{IPNS}+\mathrm{CRI}, \quad \mathrm{T}_{10}=\mathrm{STB}+\mathrm{CRI}, \quad \mathrm{T}_{11}=\mathrm{FP}+\mathrm{CRI}, \quad \mathrm{T}_{12}=\mathrm{CON}+\mathrm{CRI} \quad \mathrm{kg} \quad \mathrm{ha}^{-1}$ 
CDNPKSZnB for T. Aman rice.(Here, HYG= High Yield Goal, MYG= Moderate Yield Goal, IPNS= Integrated Nutrient Management System, STB= Soil Test Based, FP= Farmers Practice, $\mathrm{CON}=$ Control, $\mathrm{CD}=$ Cowdung and $\mathrm{CRI}=$ Crop Residue Incorporated). The previous crop mungbean was cultivated which was demarked individually plot earlier in the whole experimental area and in case of CRI plots, total biomass (except pod) of mungbean was incorporated as residue before T. Aman rice transplanting. In second year, the land was used for any rabi crop after harvest of T. Aman rice. The rates for N, P, K, S, and $\mathrm{Zn}$ application were calculated based on the soil test value following the soil test interpretation (FRG, BARC, 2005). The rate for each element was considered as $100 \%$. Accordingly, the full or $100 \%$ rate of N, P, K, S, and Zn for each crop was applied. In case of Integrated Plant Nutrient System (IPNS) treatment the amount of nutrients available in cowdung (CD) was deducted from the total amount of chemical fertilizers and adjusted accordingly. The rates for chemical fertilizers were fixed on soil test basis (STB) with a high yield goal (HYG) for specific crop basis as per BARC (FRG, BARC, 2005). The exact fertilizer nutrient for making the recommendation was computed with the following formula:

$\mathrm{F}_{\mathrm{r}}=\mathrm{U}_{\mathrm{f}}-\frac{\mathrm{C}_{\mathrm{i}}}{\mathrm{C}_{\mathrm{s}}} \times\left(\mathrm{S}_{\mathrm{t}}-\mathrm{L}_{\mathrm{s}}\right)$

Where

$F_{r}=$ Fertilizer nutrient required for a given soil test value

$\mathrm{U}_{\mathrm{f}}=$ Upper limit of the recommended fertilizer nutrient for the respective soil test value interpretation (STVI) class

$\mathrm{C}_{\mathrm{i}}=$ Units of class intervals used for fertilizer nutrient recommendation

$\mathrm{C}_{\mathrm{s}}=$ Units of class intervals used for STVI class

$\mathrm{S}_{\mathrm{t}}=$ Soil test value

$\mathrm{L}_{\mathrm{s}}=$ Lower limit of the soil test value within STVI class.

The sources of $\mathrm{N}, \mathrm{P}, \mathrm{K}, \mathrm{S}$, and $\mathrm{Zn}$ were urea, triple super phosphate (TSP), muriate of potash (MoP), gypsum, and zincsulphate, respectively. The farmers' practice (FP) for fertilizer rates was determined on the basis of data collected through interviewing thirty (30) farmers from adjacent locality. Total residue was chopped just after harvest and ploughed down to the soil by spade for decomposition in respective CRI plots. Thirty-day old seedlings were transplanted from 1-7 July each year. Three seedlings per hill were used following a spacing of $20 \mathrm{~cm} \times 15 \mathrm{~cm}$.The whole amount of TSP, MoP, gypsum and zincsulphate were applied at the time of final land preparation as per treatment. Urea was applied into three splits at 15, 30 and 45 days after 
transplanting. Intercultural operations like weeding, irrigation and pest control measures were taken as and when necessary. T. Aman rice was harvested on 2531 October each year.

The crops were harvested from $10 \mathrm{~m} 2$ at full maturity. A sub-sample of $200 \mathrm{~g}$ dry biomass for each of crop was collected for chemical (nutrient uptake) analysis. The sub-samples were dried in an oven for 72 hours at 700C. Apparent nutrient balance (added-uptake) was calculated by using the following formula.

$X a=(X f+X r+X i+X b+X c r i)-X r e m$, Where

$\mathrm{Xa}=$ Apparent gain (+) or loss (-) of nutrient $\left(\mathrm{kg} \mathrm{ha}^{-1}\right)$

$\mathrm{Xf}=$ Nutrient added through inorganic sources $\left(\mathrm{kg} \mathrm{ha}^{-1}\right)$

$\mathrm{Xr}=$ Nutrient added through rainfall $\left(\mathrm{kg} \mathrm{ha}^{-1}\right)$. (Not considered)

$\mathrm{Xi}=$ Nutrient added through irrigation water $\left(\mathrm{kg} \mathrm{ha}^{-1}\right)$. (Not considered)

$\mathrm{Xb}=$ Nutrient added through BNF $\left(\mathrm{kg} \mathrm{ha}^{-1}\right)$. (Not considered)

$\mathrm{Xcri}=$ Nutrient added through crop residue incorporation $\left(\mathrm{kg} \mathrm{ha}^{-1}\right)$.

Xrem $=$ Nutrient removed by crops and loss through different systems $\left(\mathrm{kg} \mathrm{ha}^{-1}\right)$.

The data were analyzed statistically by the F-test andthe mean comparisons of the treatments were evaluated by DMRT (Duncan's Multiple Range Test).

\section{Results and Discussion}

\section{Plant population}

Plant population was not influenced significantly by different nutrient management treatments in both the years (Table 2).

\section{Plant height}

The nutrient management treatments without or with CRI influenced the plant height significantly in both theyears. The plant height was statistically identical except control without or with crop residues incorporation (Table 2). In a field study, Basak et al. (2008 a) recorded the highest plant height with STB nutrient in T. Aman rice of Mustard-Boro rice-T. Aman rice cropping pattern and Awal et al. (2007) also reported similar result in T. Aman rice on Wheat-Jute-T. Aman rice cropping pattern.

\section{Panicles number}

Number of panicles $\mathrm{m}^{-2}$ differed significantly due to application of nutrients in soil both the years. The highest number of panicles $\mathrm{m}^{-2}$ was 250 under STB with crop residues integration, which was statistically identical with STB (249), 
IPNS+CRI (245), IPNS (243), HYG+CRI (240) and HYG (237) in 2007. In 2008 , the trend was similar. From the two years results, it was observed that the maximum panicles $\mathrm{m}^{-2}$ obtained from HYG, IPNS and STB, without or with CRI nutrient management treatments compared to other treatments. STB was the best among those treatments might be due to proper nutrient was added into the soil resulted maximum number of panicles $\mathrm{m}^{-2}$ followed by IPNS and $\mathrm{HYG}$, respectively. The lowest panicles $\mathrm{m}^{-2}$ was found in control due to lack of proper nutrient. Increased number of panicles $\mathrm{m}^{-2}$ was found in all the treatments along with CRI than without CRI which might be due to the crop residual effect (Maskina et al., 1987). Ali et al. (2003) stated that STB nutrient gave the highest panicles $\mathrm{m}^{-2}$ in T. Aman rice in Mustard-Boro rice-T. Aman and Basak et al. (2008) stated similar findings in T. Aman rice of Mustard-Boro rice-T. Aman rice cropping pattern.

\section{Grains panicle $^{-1}$}

The nutrient management treatments HYG, IPNS and STB without or with CRI produced higher number of grains panicle ${ }^{-1}$ which ranged from 78 to 88 in both the years. From the two years results, it was revealed that the nutrient management treatments HYG, IPNS and STB along with or without CRI produced the maximum number of grains panicle ${ }^{-1}$. Among those treatments, STB gave the best performance that might be due to appropriate nutrient dose applied into the soil, while the nutrient applied was higher in case of HYG. Control produced the minimum grains panicle ${ }^{-1}$ due to no addition of nutrient into the soil. However, the increasing trend was observed in all the treatments along with CRI than without CRI which might be due to the effect of crop residues (Naser et al., 2001). However, there was no significant difference between with or without CRI. These findings were similar to the findings of Zaman et al., 2007 a \& b; Awal et al., 2007.

\section{Sterile spikelet panicle ${ }^{-1}$}

The number of sterile spikelets panicle ${ }^{-1}$ differed significantly due to application of different nutrients without or with incorporation of crop residues. The highest number of sterile spikelets panicle ${ }^{-1}$ was 57 under control without CRI followed by with control with CRI (57). In case of other nutrient management treatments the number of sterile spikelets panicle ${ }^{-1}$ ranged from 32 to 42 . The lowest sterile spikelets panicle $^{-1}$ (32) was obtained with HYG treatment without CRI. Similar trend was found in 2008 (Table 3).The highest number of sterile spikelets panicle $^{-1}$ in case of control without or with CRI might be due to the absence of proper nutrients in the soil. HYG, IPNS and STB without or with CRI produced the minimum number of sterile spikelets panicle ${ }^{-1}$. 


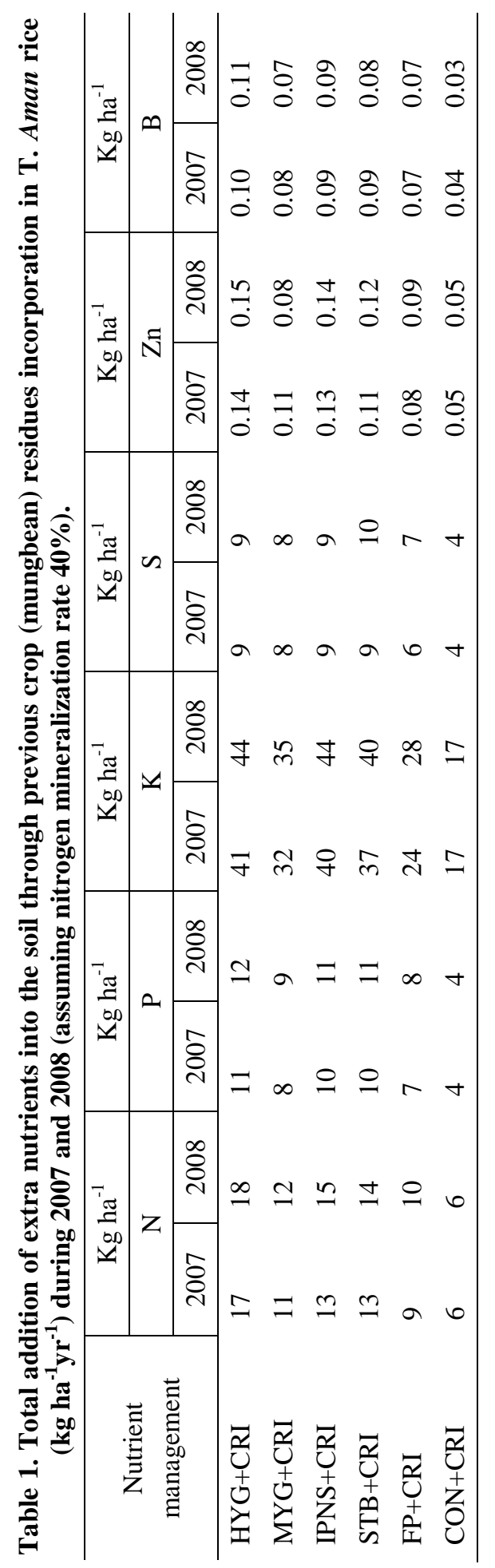




\section{Grain weight}

Different nutrient management treatments over the years did not influence 1000grain weight significantly (Table 3 ).

\section{Grain yield}

The grain yield irrespective of treatment was found slightly higher in 2008 than 2007 (Table 3). It was observed that HYG, IPNS and STB nutrient management treatments without or with crop residues incorporation produced the maximum grain yield and those were statistically identical over the years. Among those treatments, STB gave the highest yield, which might be due to the combined effect of higher number of tillers $\mathrm{m}^{-2}$, panicles $\mathrm{m}^{-2}$ and grains panicle ${ }^{-1}$. MYG and FP without or with CRI gave average and low grain yield, respectively might be due to the effect of moderate and low number of tillers $\mathrm{m}^{-2}$, panicles $\mathrm{m}^{-2}$ and grains panicle ${ }^{-1}$. The lowest grain yield was found in control treatment. However, the grain yield in all the treatments with CRI was found superior to without CRI that might be due to the effect of conservation agriculture, more soil microbial activities through crop residual incorporation resulting the yield was increased (Kavimadan et al., 1987 and Ladha et al., 1987). Moreover, the overall trend was similar in both the years. These results are in agreement with that of Akhteruzzaman et al. (2009). On an average, maximum grain yield (5.24 t ha $\left.{ }^{-1}\right)$ was recorded from STB+CRI followed by IPNS+CRI, STB and IPNS. It is noted that STB, IPNS and incorporation of residues played vital role in increasing grain yield as well as improved of soil health. Timsina et al. (2006 a) reported the highest grain yield with STB nutrient in T. Aman rice on rice-wheat system. Similar findings were also reported by many scientists (Quayyum et al., 2001 and 2002; Chowdhury et al., 2002; Basak et al., 2008 a; Roy et al., 2008; Ali et al., 2003).

\section{Straw yield}

The significantly highest straw yield was $6.43 \mathrm{t} \mathrm{ha}^{-1}$ in HYG+CRI which was identical to IPNS+CRI $\left(6.29 \mathrm{t} \mathrm{ha}^{-1}\right)$, HYG $\left(6.26 \mathrm{t} \mathrm{ha}^{-1}\right)$, IPNS $\left(6.13 \mathrm{t} \mathrm{ha}^{-1}\right)$. MYG treatment yielded similar to STB. FP gave low straw yield without or with crop residue incorporation. The lowest straw yield was $1.44 \mathrm{t} \mathrm{ha}^{-1}$ under control without CRI. In 2008, the trend was similar to the previous year. However, the highest straw yield was $6.92 \mathrm{tha}^{-1}$ under HYG+CRI and the lowest was $1.69 \mathrm{t}$ ha 1 in control without CRI (Table 3).Among the treatments, HYG gave the maximum straw yield which was followed by IPNS and STB, which might be contributed through plant height and biomass. The straw yield was higher in all the treatments along with CRI than without CRI, might be due to the residual effect of the crop (Thakur and Singh, 1987; Kavimadan et al. 1987 and Ladha et al. 1987). 


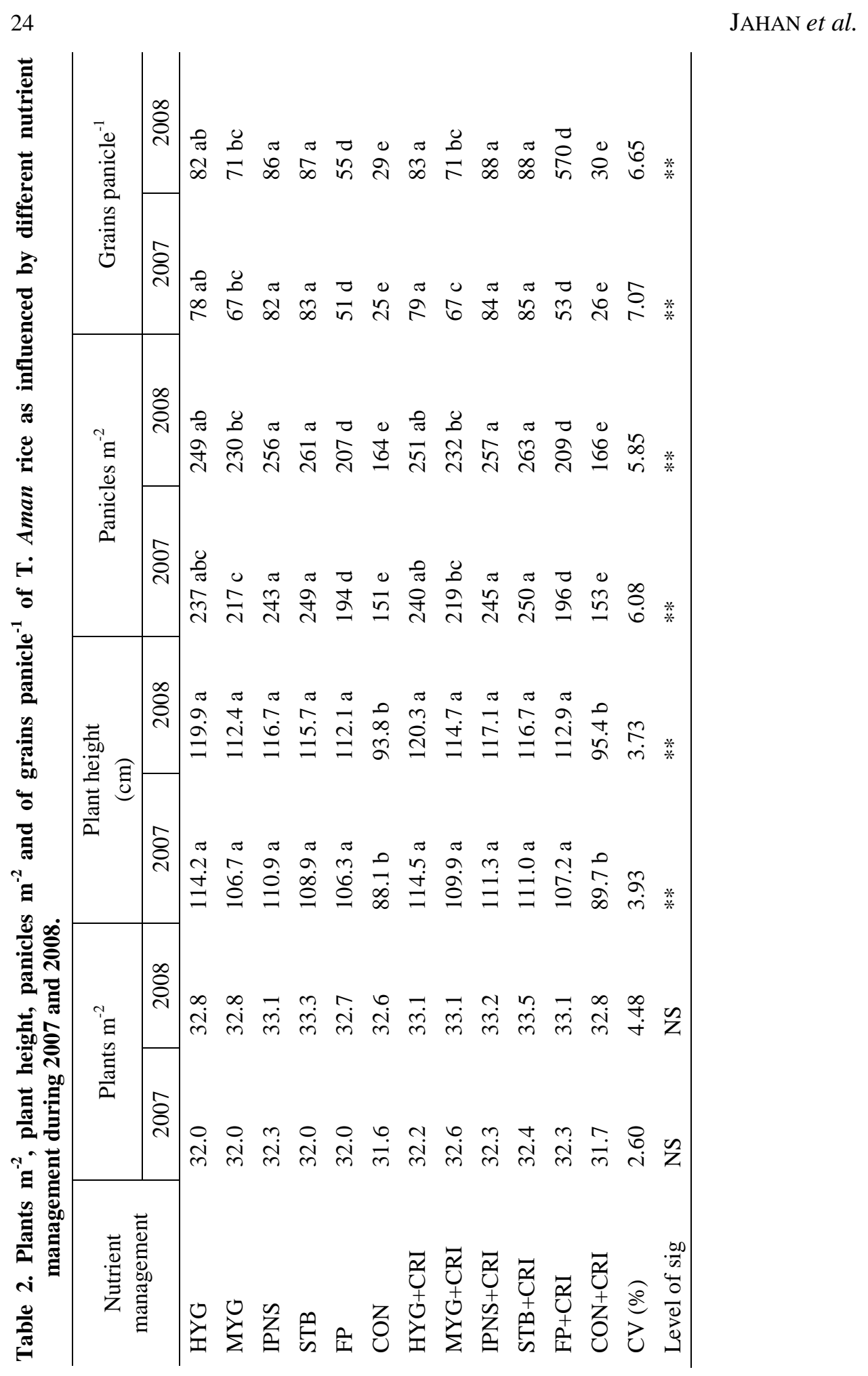


GRAIN YIELD, NUTRIENT BALANCE AND ECONOMICS

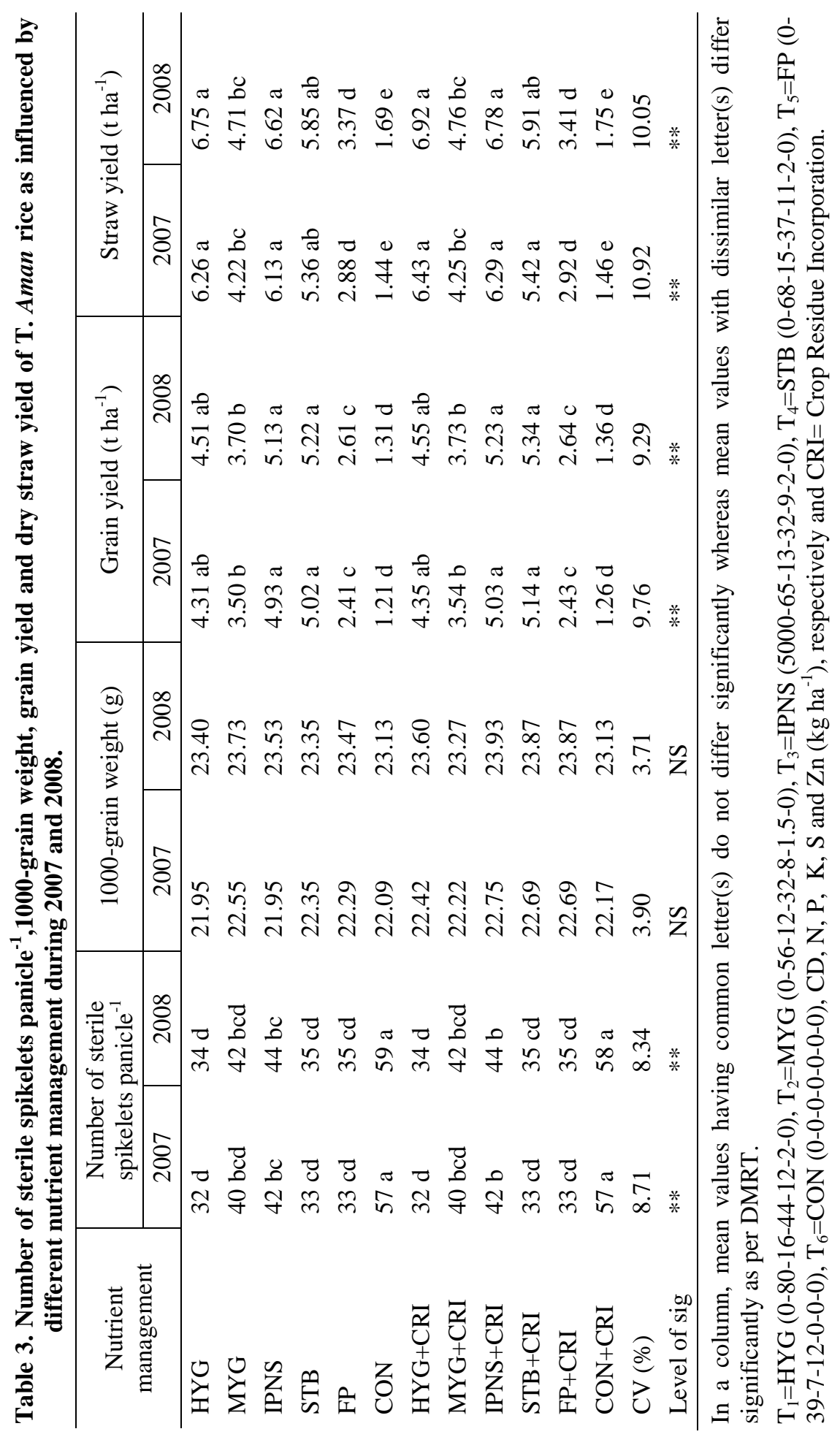




\section{Apparent nutrient uptake and balance}

\section{Nitrogen}

From the mean data it was observed that the added of nutrient ranged from 0 to $55 \mathrm{~kg} \mathrm{ha}^{-1} \mathrm{yr}^{-1}$ (40\% of applied chemical/cowdung/crop residues nutrient $\mathrm{N}$ was considered effective) while uptake ranged from 25 to $116 \mathrm{~kg} \mathrm{ha}^{-1} \mathrm{yr}^{-1}$ among different treatments (Fig.1). Maximum uptake was found in IPNS+CRI (116 kg $\left.\mathrm{ha}^{-1} \mathrm{yr}^{-1}\right)$ followed by STB+CRI $\left(115 \mathrm{~kg} \mathrm{ha}^{-1} \mathrm{yr}^{-1}\right)$. Minimum uptake was estimated in CON $\left(25 \mathrm{~kg} \mathrm{ha}^{-1} \mathrm{yr}^{-1}\right)$. The apparent nutrient balance was found negative in all treatments ranging from -20 to $-82 \mathrm{~kg} \mathrm{ha}^{-1} \mathrm{yr}^{-1}$. The highest negative balance was found in STB $\left(-82 \mathrm{~kg} \mathrm{ha}^{-1} \mathrm{yr}^{-1}\right)$ followed by IPNS $\left(-68 \mathrm{~kg} \mathrm{ha}^{-1} \mathrm{yr}^{-1}\right)$. The lowest negative balance was observed in CON+CRI $\left(-20 \mathrm{~kg} \mathrm{ha}^{-1} \mathrm{yr}^{-1}\right)$. Fig. 1 , showed that the nitrogen balance was negative as the uptake was higher compared to added nitrogen (40\% of applied chemical/cowdung/crop residues nutrient $\mathrm{N}$ was considered effective). Nitrogen replenishment through chemical fertilizer, cowdung addition, crop residue incorporation either singly or in combination was not enough to balance $\mathrm{N}$ removal by crop; so much of the applied $\mathrm{N}$ was lost from the soil through depletion. The $\mathrm{N}$ balance thus was negative in all treatments appeared to have been removed in excess of the quantity added in soil. However, the $\mathrm{N}$ balance was less negative in those treatments where crop residues were incorporated than without incorporation which might be due to addition of extra $\mathrm{N}$ came from previous crop residues (6 to $18 \mathrm{~kg} \mathrm{ha}^{-1} \mathrm{yr}^{-1}$ ) as shown (Table 1). Present findings are also in agreement with the observation of Timsina et al., 2001, 2006 (b) and Rahman et al., 1998.

\section{Phosphorus}

The added phosphorus was in the range from 0 to $28 \mathrm{~kg} \mathrm{ha}^{-1} \mathrm{yr}^{-1}$ in respective of different treatments. The uptake was ranged from 5 to $26 \mathrm{~kg} \mathrm{ha}^{-1} \mathrm{yr}^{-1}$. The treatment IPNS+CRI showed maximum uptake $\left(26 \mathrm{~kg} \mathrm{ha}^{-1} \mathrm{yr}^{-1}\right)$ followed by STB+CRI $\left(25 \mathrm{~kg} \mathrm{ha}^{-1} \mathrm{yr}^{-1}\right)$. The lowest uptake was found in CON and CON+CRI $\left(5 \mathrm{~kg} \mathrm{ha}^{-1} \mathrm{yr}^{-1}\right)$. Only control plot along with or without CRI treatments showed negative balance ranged from -1 to $-5 \mathrm{~kg} \mathrm{ha}^{-1} \mathrm{yr}^{-1}$ and remaining all the treatments showed positive balance ranged from 1 to $7 \mathrm{~kg} \mathrm{ha}^{-1} \mathrm{yr}^{-1}$ (Fig. 2). From the figure 2, it was observed that except control plots along with or without CRI treatments, all treatments showed positive balance due to addition of higher amount of phosphorus while uptake was lower that might be due to total dry matter content as well as the variation of concentration of the nutrient of the crops. In HYG, MYG, IPNS, STB and FP along with or without CRI treatments the balance appeared positive with trace amount due to addition of adequate nutrient into the soil whereas uptake was a little bit lower. However, the positive balance was higher in those treatments where the crop residue were incorporated with soil than without incorporated treatments which might be due to addition of extra nutrient in the range of $4-12 \mathrm{~kg} \mathrm{ha}^{-1} \mathrm{yr}^{-1}$ from the mean data (Table 1). Similar results were also found by Saleque et al. (2006). 


\section{Potassium}

The quantity of added nutrient (K) was in the range of 0 to $87 \mathrm{~kg} \mathrm{ha}^{-1} \mathrm{yr}^{-1}$ and uptake by the crop varied from 22 to $116 \mathrm{~kg} \mathrm{ha}^{-1} \mathrm{yr}^{-1}$. Maximum uptake was found in STB+CRI (116 kg ha $\left.\mathrm{yr}^{-1}\right)$ followed by IPNS (104 $\left.\mathrm{kg} \mathrm{ha}^{-1} \mathrm{yr}^{-1}\right)$. Minimum uptake was observed in CON $\left(22 \mathrm{~kg} \mathrm{ha}^{-1} \mathrm{yr}^{-1}\right)$. Among the nutrient managements, all treatments showed negative balance in the range of -1 to $-66 \mathrm{~kg} \mathrm{ha}^{-1} \mathrm{yr}^{-1}$. Maximum negative balance was observed in STB (-66 $\left.\mathrm{kg} \mathrm{ha}^{-1} \mathrm{yr}^{-1}\right)$ and minimum was found in MYG+CRI (-1 kg ha $\left.\mathrm{yr}^{-1}\right)$ as shown in Fig. 3. However, the negative balance was shown lower in those treatments where crop residues were incorporated than without incorporated plots. It might happen due to addition of extra nutrient in the range of 17 to $44 \mathrm{~kg} \mathrm{ha}^{-1} \mathrm{yr}^{-1}$ from the mean data through crop residues incorporation (Table 1). This result is also agreement with Panaullah et al. (2006).

\section{Sulphur}

From the mean data it was observed that quantity of added nutrient ranged from 0 to $21 \mathrm{~kg} \mathrm{ha}^{-1} \mathrm{yr}^{-1}$ and the uptake ranged from 4 to $19 \mathrm{~kg} \mathrm{ha}^{-1} \mathrm{yr}^{-1}$ with irrespective treatments. Among the treatments, maximum uptake was observed in STB+CRI (19 $\left.\mathrm{kg} \mathrm{ha}^{-1} \mathrm{yr}^{-1}\right)$ followed by IPNS+CRI and HYG+CRI (17 $\left.\mathrm{kg} \mathrm{ha}^{-1} \mathrm{yr}^{-1}\right)$. Minimum uptake was found in CON $\left(4 \mathrm{~kg} \mathrm{ha}^{-1} \mathrm{yr}^{-1}\right)$. The negative balance was observed in FP and CON with and without CRI treatments was -1 to $-8 \mathrm{~kg} \mathrm{ha}^{-1} \mathrm{yr}^{-}$ ${ }^{1}$. Remaining treatments showed positive balance ranged from 1 to $4 \mathrm{~kg} \mathrm{ha}^{-1} \mathrm{yr}^{-}$ ${ }^{1}$ (Fig.4). Among the treatments, the maximum positive balance was observed in $\mathrm{HYG}+\mathrm{CRI}$ and IPNS+CRI $\left(4 \mathrm{~kg} \mathrm{ha}^{-1} \mathrm{yr}^{-1}\right)$ followed by MYG+CRI $\left(2 \mathrm{~kg} \mathrm{ha}^{-1} \mathrm{yr}^{-1}\right)$. This result is in agreement with Khan et al. (2005).

\section{Zinc}

The amount of nutrient added in different nutrient treatment was in the range of 0 to $2.15 \mathrm{~kg} \mathrm{ha}^{-1}$ and uptake was in the range 0.12 to $0.65 \mathrm{~kg} \mathrm{ha}^{-1} \mathrm{yr}^{-1}$ with different treatments shown in Fig 5. Maximum uptake was observed in STB $(0.65 \mathrm{~kg}$ ha $\left.\mathrm{yr}^{-1}\right)$ that was followed by IPNS $\left(0.64 \mathrm{~kg} \mathrm{ha}^{-1} \mathrm{yr}^{-1}\right)$. Minimum uptake was found in CON $\left(0.12 \mathrm{~kg} \mathrm{ha}^{-1} \mathrm{yr}^{-1}\right)$. The highest negative balance was noticed in FP $(-0.31$ $\left.\mathrm{kg} \mathrm{ha}^{-1} \mathrm{yr}^{-1}\right)$ and the lowest in CON+CRI $\left(-0.08 \mathrm{~kg} \mathrm{ha}^{-1} \mathrm{yr}^{-1}\right)$. Other treatments showed positive balance ranged from 1.12 to $1.61 \mathrm{~kg} \mathrm{ha}^{-1} \mathrm{yr}^{-1}$. Among the treatments, maximum positive balance was noticed in $\mathrm{HYG}+\mathrm{CRI}\left(1.61 \mathrm{~kg} \mathrm{ha}^{-1} \mathrm{yr}^{-}\right.$ ${ }^{1}$ ) followed by IPNS+CRI (1.54 $\left.\mathrm{kg} \mathrm{ha}^{-1} \mathrm{yr}^{-1}\right)$. Minimum positive balance was observed in MYG (1.12 kg ha $\left.\mathrm{yr}^{-1}\right)$. From the mean data of two years, it was noticed that farmers' practice and control treatments showed negative balance of zinc. Because there was poor and no nutrient (native nutrient was available only in the soil) was added into the soil whereas a considerable amount of nutrient was removed by the crop through total dry matter weight and nutrient concentration 
variation in respective treatments consequently the balance became negative. Similar results were reported by Bhuiyan (2004) in wheat-T. Aus/MungbeanT.Aman rice cropping pattern and Basak et al. (2008) in Groundnut-T.AusT.Aman rice cropping pattern.

\section{Boron}

The range of added boron was 0 to $0.11 \mathrm{~kg} \mathrm{ha}^{-1} \mathrm{yr}^{-1}$ and uptake ranged from 0.04 to $0.27 \mathrm{~kg} \mathrm{ha}^{-1} \mathrm{yr}^{-1}$. The uptake was the highest in both IPNS and STB $(0.27 \mathrm{~kg}$ $\left.\mathrm{ha}^{-1}\right)$ and the lowest uptake in CON $\left(0.04 \mathrm{~kg} \mathrm{ha}^{-1} \mathrm{yr}^{-1}\right)$ in Fig. 6. The highest negative balance was found in both IPNS and STB $\left(-0.27 \mathrm{~kg} \mathrm{ha}^{-1} \mathrm{yr}^{-1}\right)$ and the lowest negative balance was observed in CON+CRI $\left(-0.01 \mathrm{~kg} \mathrm{ha}^{-1} \mathrm{yr}^{-1}\right)$. From the above results, it was observed that the balance was negative in all the treatments due to no addition of born nutrient in the soil from external sources (native boron available in the soil only). Although some amount of nutrient was removed by the plants for total dry matter production and variation of nutrient concentration (concentration table was not shown here). Similar results were reported by Bhuiyan (2004) in Wheat-T. Aus/ Mungbean- T. Aman rice cropping pattern.

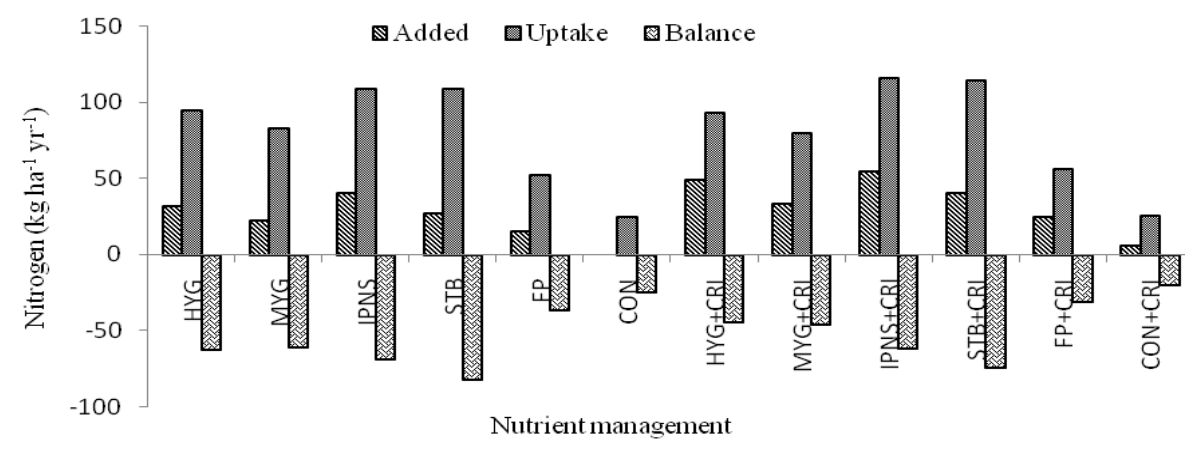

Fig. 1. Apparent $\mathrm{N}$ balance of $\mathrm{T}$. Aman rice as influenced by different nutrients management (two years mean).

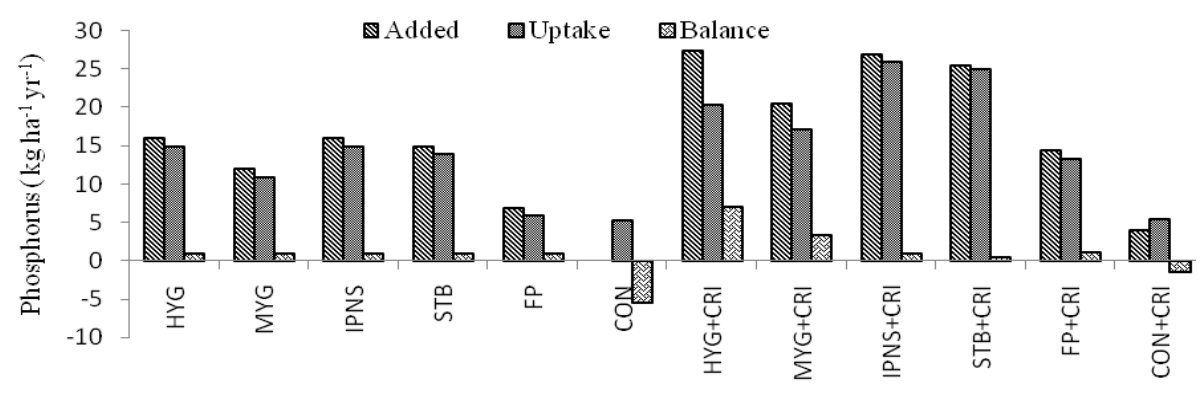

Nutrient management

Fig. 2. Apparent $P$ balance of $T$. Aman rice as influenced by different nutrients management (two years mean). 


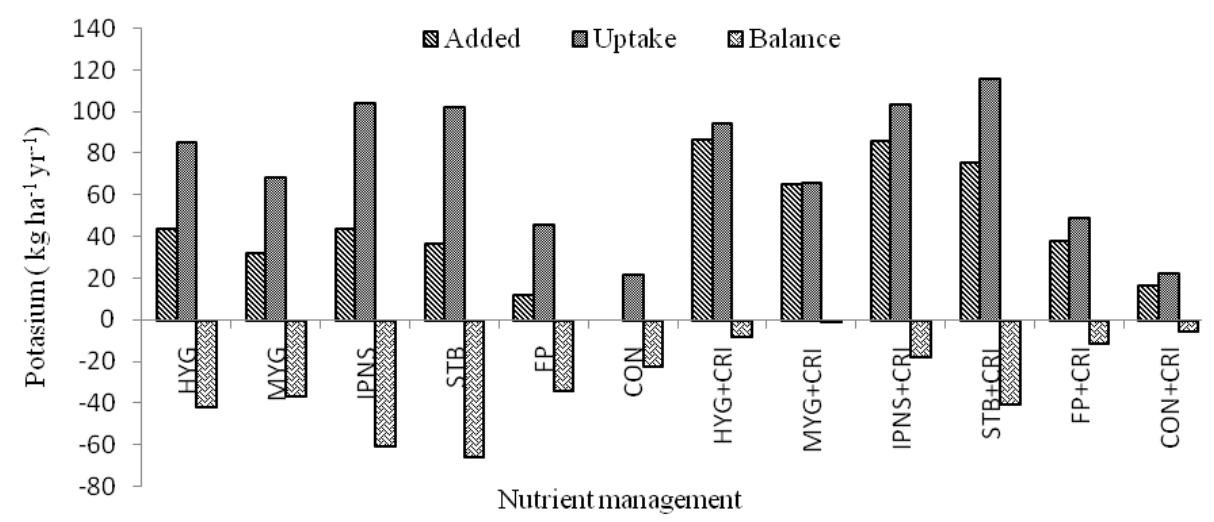

Fig. 3. Apparent $\mathrm{K}$ balance of $\mathrm{T}$. Aman rice as influenced by different nutrients management (two years mean).

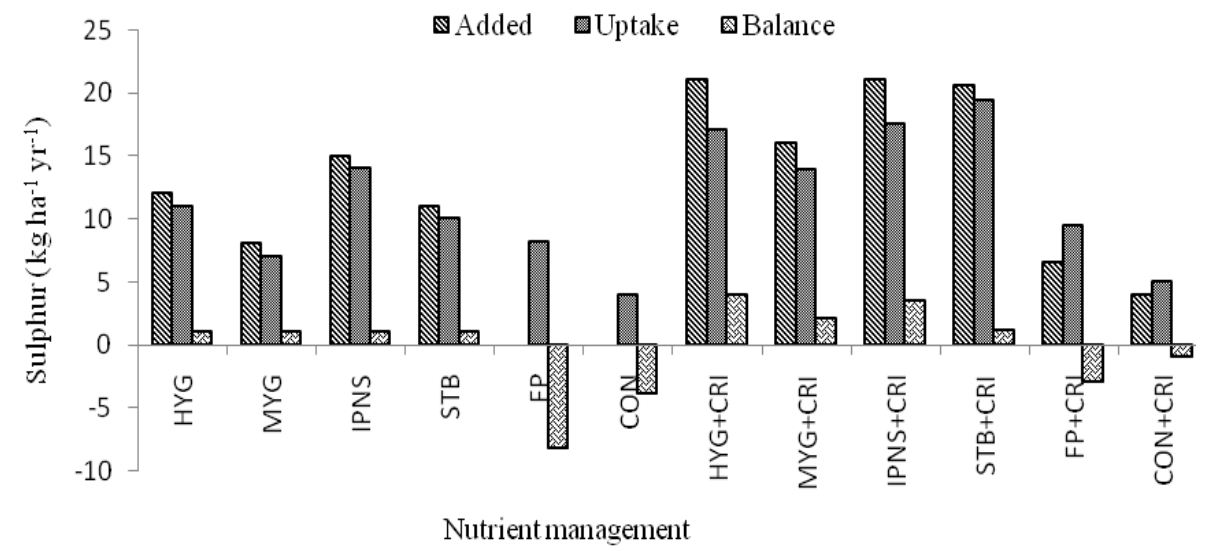

Fig. 4. Apparent $\mathrm{S}$ balance of T. Aman rice as influenced by different nutrients management (two years mean).

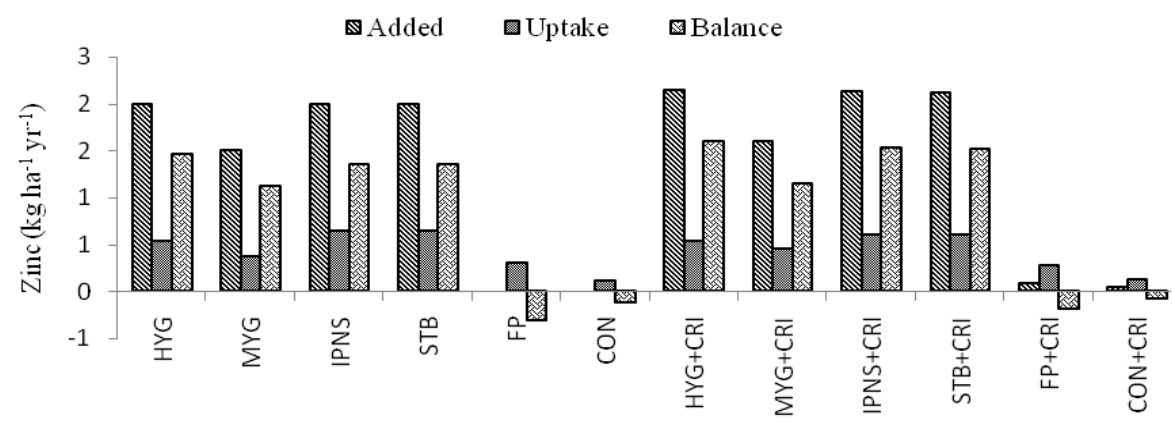

Nutrient management

Fig. 5. Apparent $\mathrm{Zn}$ balance of T. Aman rice as influenced by different nutrients management (two years mean). 


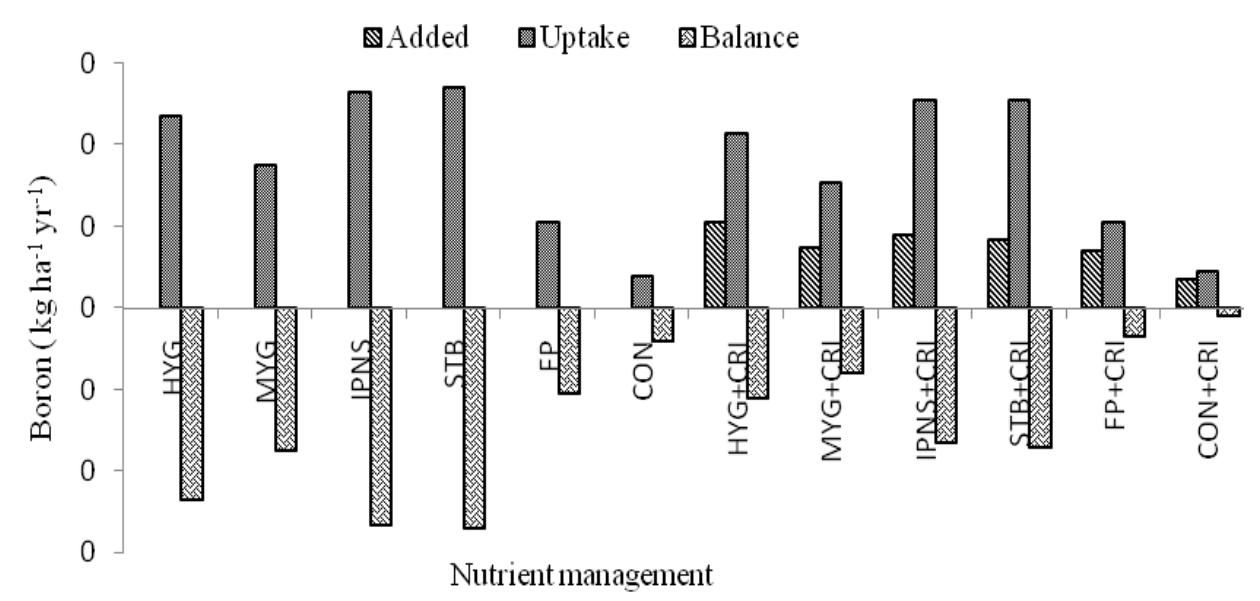

Fig. 6. Apparent B balance of T. Aman rice as influenced by different nutrients management (two years mean).

\section{Economics of mungbean cultivation as influenced by different nutrient managements}

Average of two years result showed that STB+CRI nutrient management gave the highest gross return (Tk. $55738 \mathrm{ha}^{-1}$ ) followed by IPNS+CRI (Tk. $54568 \mathrm{ha}^{-}$ ${ }^{1}$ ), STB (Tk.54420 ha $\mathrm{h}^{-1}$ ) and IPNS (Tk. $53520 \mathrm{ha}^{-1}$ ) nutrient management treatments due to higher yield. Similar trend was followed in gross margin and net return. Due to higher yield obtained from STB nutrient management, higher BCR (3.25) followed by STB+CRI (3.14), IPNS (2.98) and IPNS+CRI (2.87). Similarly, the highest MBCR was found in STB (9.97) followed by STB+CRI (8.23) due to comparatively lower variable cost. Control plots produced the lowest gross return, gross margin, net return and BCR due to low yield (Table 4). The overall economic performance of the aforesaid of T. Aman rice is sustainable, considering applied STB nutrient management. STB+CRI nutrient management also gave higher gross margin, net return and BCR compared to other nutrient managements like STB. Many scientists (Ali et al., 2009; Biswas et al., 2004, 2007, 2008; Zaman et al., 2007 a \& b) also reported that conducted similar type of experiments with different cropping patterns without crop residue incorporation into the soil and found more or less similar results. However, STB and IPNS nutrient managements along with and without crop residue incorporation might be suitable for T. Aman rice production in economic point of view. 
Table 4. Economic performance of T. Aman rice as influenced by different nutrient managements (mean of 2007 and 2008).

\begin{tabular}{l|c|c|c|c|c|c|c}
\hline $\begin{array}{c}\text { Nutrient } \\
\text { management }\end{array}$ & $\begin{array}{c}\text { Total } \\
\text { cost } \\
\text { (Taka) }\end{array}$ & $\begin{array}{c}\text { Variable } \\
\text { Cost } \\
\text { (Taka) }\end{array}$ & $\begin{array}{c}\text { Gross } \\
\text { return } \\
\text { (Taka) }\end{array}$ & $\begin{array}{c}\text { Gross } \\
\text { margin } \\
\text { (Taka) }\end{array}$ & $\begin{array}{c}\text { Net } \\
\text { return } \\
(\text { Taka })\end{array}$ & BCR & $\begin{array}{c}\text { MBCR } \\
\text { over } \\
\text { control) }\end{array}$ \\
\cline { 2 - 8 } HYG & 17310 & 4661 & 46903 & 42242 & 29593 & 2.71 & 7.19 \\
MYG & 16033 & 3384 & 38233 & 34849 & 22200 & 2.38 & 7.35 \\
IPNS & 17972 & 5323 & 53520 & 48197 & 35548 & 2.98 & 7.54 \\
STB & 16767 & 4118 & 54420 & 50302 & 37653 & 3.25 & 9.97 \\
FP & 14412 & 1763 & 26663 & 24900 & 12251 & 1.85 & 7.54 \\
CON & 12649 & 0 & 13383 & 13383 & 734 & 1.06 & CON \\
HYG+CRI & 18330 & 5681 & 47333 & 41652 & 29003 & 2.58 & 5.98 \\
MYG+CRI & 16963 & 4314 & 38603 & 34289 & 21640 & 2.28 & 5.85 \\
IPNS+CRI & 18987 & 6338 & 54568 & 48230 & 35581 & 2.87 & 6.50 \\
STB+CRI & 17797 & 5148 & 55738 & 50590 & 37941 & 3.14 & 8.23 \\
FP+CRI & 15172 & 2523 & 26933 & 24410 & 11761 & 1.78 & 5.37 \\
CON+CRI & 13179 & 530 & 13903 & 13373 & 724 & 1.06 & 0.98 \\
\hline
\end{tabular}

$\mathrm{HYG}=0-80-16-44-12-2-0, \mathrm{MYG}=0-56-12-32-8-1.5-0, \mathrm{IPNS}=5-65-13-32-9-2-0, \mathrm{STB}=0-$ 68-15-37-11-2-0, FP=0-39-7-12-0-0-0, CON=0-0-0-0-0-0-0, CD (t ha $\left.{ }^{-1}\right), \mathrm{N}, \mathrm{P}, \mathrm{K}, \mathrm{S}, \mathrm{Zn}$, $\mathrm{B}\left(\mathrm{kg} \mathrm{ha}^{-1}\right)$, respectively and $\mathrm{CRI}=$ Crop Residue Incorporation.

Input and output prices: Urea-6.50 (Tk. $\left.\mathrm{kg}^{-1}\right)$, TSP-19.00, MP-15.00, Gypsum-4.60, Zincsulphate-65.00, Boric acid-100, Cowdung-0.32 and Crop reside- 0.50 (dry basis), (Tk. $\mathrm{kg}^{-1}$ ) Rice grain-10 and Rice straw-0.50 (dry basis)

\section{Conclusion}

Soil test based and integrated plant nutrient system nutrient management along with or without crop residue incorporation could be suitable for getting economically higher grain yield of T. Aman rice keeping improvement soil health.

\section{References}

Akhteruzzaman, M., N.A. Mondal, K.U. Ahammad, J.A. Mahmud and M.A.H.S. Jahan. 2009. Integrated nutrient management for Wheat-Mungbean-T. Amanrice cropping pattern in high Ganges river floodplain soil. Eco-friendly Agril. J. 2(1): 322-326.

Ali, M.R., M.S. Rahman, M.A. Mannan, M.M. Hossain and M. Kadir. 2009. Balanced fertilization with inorganic fertilizers in Mustard-Boro-T. Aman cropping pattern. Bangladesh J. Prog. Sci. \& Tech. 1(1): 33-37. 
Awal, M.A., M.A.H. Bhuiyan, M.S. Rahman and M.R. Ali. 2007. Profitability of recommended fertilizer on Wheat-Jute-T. Aman cropping pattern under irrigated condition. Bangladesh J. Agric. and Environ. 3(1): 47-55.

BARC (Bangladesh Agricultural Research Council). 2005. Fertilizer Recommendation Guide-2005. Bangladesh Agril. Res. Council, New Airport Road, Farmgate, Dhaka.

Basak, N.C., M.A. Quayyum, S.M.Asaduzzaman, N. Sultana and M.A.H. Khan.2008. Integrated nutrient management in the Mustard-Boro rice-T.Aman rice cropping system. Bangladesh J. Agril. Res. 33(1): 135-143.

BBS (Bangladesh Bureau of Statistics). 2012. Statistical Year Book of Bangladesh. Bangladesh Bur. Stat., Plan. Div., Minis.Plan., Govt. People's Repub. Bangladesh. Dhaka, Bangladesh. Pp. 27-29.

BER. 2010.Bnagladesh Economic Review, Department of Finance, Ministry of Finance, Govt. of the People's Republic of Bangladesh, Dhaka.

Bhuiyan, M.A.H. 2004. Evaluation of introducing mungbean into cereal based cropping pattern for sustainable soil fertility and productivity. Ph D Thesis. Dept. of Soil Science, Bangladesh Agricultural University (BAU), Mymensingh.

Biswas, J.C., M. Maniruzzaman, M.A. Sattar and M.G. Neogi. 2008. Improvement of existing rice yield through recommended fertilizer and cultural management at farmers' fields. Bangladesh Rice J. 13(1): 9-14.

Biswas, J.C., M.R. Islam and M.J. Islam. 2007. Crop Productivity as influenced by soil test based fertilizer management in six cropping patterns at farmers' field. SAARC J. of Agri. 5(1): 33-42.

Biswas, J.C., M.R. Islam, S.R. Biswas and M.J. Islam. 2004. Crop productivity at farmers field options for soil test based fertilizer use and cropping patterns. Bangladesh Agron. J. 10(1\&2): 31-41.

Chowdhury, J.A., M.A. Quayyum, J.Timsina, F. Haq and D.J. Connor. 2002. System productivity for Wheat-Mungbean/Maize-Rice sequences in northwest of Bangladesh. Bangladesh J. Agril. Res. 27(4): 619-627.

Das, K., D.N. Medhi and B. Guha. 2003. Application of crop residues in combination with chemical fertilizers for sustainable productivity in rice (Oryza sativa)-wheat (Triticum aestivum) system. Indian Journal of Agronomy 48 (1): 8-11.

Kavimadan, S.K., J.P. Gupta and I.C.Mahapatra. 1987. Studies on residue management and biofertilizers in Rice-Wheat sequence. Indian J. Agron. 32(3): 278-279.

Khan, M.A.H., M.A. Quayyum, D.A. Choudhury, M.I. Nazrul and M.R. Ali. 2005. Integrated nutrient management for Potato-T. Aus-T. Aman rice cropping system. Bangladesh Agron. J. 11(1 \& 2): 89-96.

Ladha, J.K., T. Padre, M.L.G. Daroy, S. Penzalan and I. Watanabe. 1987. The effects of $\mathrm{N}_{2}$ fixation $\left(\mathrm{C}_{2} \mathrm{H}_{2}\right.$ reduction), bacterial population and rice plant growth of two modes of straw application to a wetland rice field. Biol. Fertil. Soils. 5:106-111. 
Maskina, M.S., Y. Singh and B. Singh. 1987. Wheat straw management for rice on a coarse textured soil. Intl. Rice Res. Newsl. 12(2): 40.

Naser, H.M., N.C. Basak and M.F. Islam. 2001. Effect of rice straw and chemical fertilizers on the productivity and economics of Boro rice-Transplanted Aman rice system. Online J. Biol. Sci. 1(9): 831-834.

Nyborg, M., E.D. Solberg, S.S. Malhi and R.C. Izaurralde. 1995. Fertilizer N, Crop residue, and tillage alter soil $\mathrm{C}$ and $\mathrm{N}$ content in a decade. p. 93-98. IN R. Lal et al. (ed.) Soil management and greenhouse effect. Adv. Soil Sci., CRC Lewis Publishers, Boca Raron, FL. In : Milkha S. Aulakh, T. S. Khera, John W. Doran and Kevin F. Bronson.2001. Soil Science Society of American Journal 65: 820-827.

Panaulah, G.M., M.A. Saleque, J. Timsina, M. Ishaque, A.B.M.B.U. Pathan, M.A. Quayyum, D.J. Connor, P.K. Saha, E. Humphreys and C.A. Meisner. 2006. Nutrient uptake and apparent balances for Rice-Wheat sequences. III. Potassium. Journal of Plant Nutrition. 29: 173-187.

Pingali, P.L., M. Hossain and R. V. Gerpacio. 1997. The Asian rice bowls: The returning Crisis? CAB International, London and IRRI, MCPO box 3217. Makati 1271, Philippines.

Quayyum, M.A., J. Timsina, F. Haq, G.S. Torofder and D.J. Connor. 2001. Effect of fertilizer and pre-monsoon crops on productivity of Rice (Oryza sativa)-Wheat (Triticum aestivum) cropping systems. Indian J. Agron. 46 (4): 584-591.

Quayyum, M.A., J. Timsina, M.A.H.S. Jahan, R. Ara and D.J. Connor. 2002. Grain Yield and System Productivity for Rice-Wheat-Mungbean and Rice-Wheat-Maize Sequences in Northern Bangladesh. Thai J. Agric. Sci. 35(1): 51-62.

Rahman, M.A., M.A. Gaffar;S M A Hossain and A M M Tareque. 1998. Nitrogen balance sheet under forage cropping system in the Old Brahmaputra Flood Plain Soils. Indian J. Agron. 43(2):269-272.

Roy, B.C., J.C. Biswas and M.R. Mandal. 2008. Spikelet fertility improvement in rice through nutrient management. Bangladesh Rice J. 13(1): 75-78.

Saleque, M.A., J., Timsina, G.M. Panaulah, M. Ishaque, A.B.M.B.U. Pathan, M.A. Quayyum, D.J. Connor, P.K. Saha, E. Humphreys and C.A. Meisner. 2006. Nutrient uptake and apparent balances for Rice-Wheat sequences. II. Phosphorus. Journal of Plant Nutrition. 28: 157-172.

Thakur, K.S. and C. M. Singh. 1987. Effect of organic wastes and N levels on transplanted rice. Indian J. Agron. 32(2): 161-164.

Timsina, J., G. M. Panaulah, M. A. Saleque, M. Ishaque, A. B. M. B. U Pathan, M. A. Quayyum, D. J. Connor, P. K. Saha, E. Humphreys and C.A. Meisner. 2006 (b).Nutrient uptake and apparent balances for Rice-Wheat sequences. I. Nitrogen. Journal of Plant Nutrition 29: 137-155.

Timsina, J., M.A. Quayyum, D.J. Connor, M. Saleque, F. Haq, G.M. Panaullah, M.A. H.S. Jahan and R.A. Begum.2006 (a).Effect of fertilizer and mungbean residue 
management on total productivity, soil fertility and N-use efficiency of intensified Rice-Wheat systems. International Journal of Agricultural Research 1(1): 41-52.

Timsina, J., U. Singh, M. Badaruddin, C.A. Meisner and M.R. Amin. 2001. Cultivar, nitrogen and water effects on productivity and nitrogen-use efficiency and balance for rice-wheat sequences of Bangladesh.Field Crop Research. 72: 143-161.

Walters, D.T., M.S. Aulakh and J.W. Doran. 1992. Effects of soil aeration, legume residue and soil texture on transformations of macro and micro nutrients in soils. Soil Sci. 153(2): 100-107.

Zaman, S., M. Saifullah and S.M. Nabi.2007 (a).Response of potato to chemical fertilizers and organic manure in old Meghna estuarine floodplain. Bangladesh $J$. Agril. Res. 25(3): 521-527.

Zaman, S.M., M.R. Amin, M.Y. Ali, M.A. Hossain and Shamima Aktar.2007 (a).Nutrient management in Boro-T.Aman cropping system under high Ganges river floodplain soil. Bangladesh J. Agron. and Environ. 3(2):55-63.

Zaman, S.M., M.R. Amin, Q. Naher, S. Aktar, M.K. Uddin and M.S. Rahman. 2007 (b). Evaluation of different nutrient management packages in Sesame-T. Aman cropping system under Ganges tidal floodplain. Intl. J. BioRes. 2(4):1-5. 